density greater than a certain critical value, the behaviour is generally similar to that of the incompressible fluid, but that for lower densities equatorial break-up, by ejection of matter from the equator, will occur. These results were applied to the evolution of the solar system, binary stars and spiral nebulæ in an essay that was awarded the Adams Prize in 1916. The conception of gravitional instability as a cause of the separation of primitive material was due to Jeans. In his important investigations in stellar dynamics, the methods that he had developed for the kinetic theory of gases were applied to the stars.

IN recent years, Jeans has written a number of popular books on astronomy and physics which have had a world-wide circulation and have done much to create an interest in the more recent developments in these branches of science. Jeans served as secretary of the Royal Society from 1919 until 1929, and as president of the Royal Astronomical Society from 1925 until 1927. He received a Royal Medal of the Royal Society in 1919 and the Gold Medal of the Royal Astronomical Society in 1922. He was president of the British Association in 1934, and president of the Indian Science Congress at its jubilee meeting in 1938 .

\section{New Year Honours}

THE following names of men of science and others associated with scientific work also appear in the New Year Honours list: Baronet: Hon. Surgeon Commander J. D. Pollock, for benefactions and services to education. G.C.M.G.: Lord Hailey, director of the African Research Survey. G.C.V.O. : Sir John Reith. G.B.E.: Sir Frank Smith, Secretary of the Department of Scientific and Industrial Research, lately secretary of the Royal Society. K.C.M.G.: Sir Algernon Aspinall, lately secretary to the West India Committee. Knights : The Hon. Walter Gordon Duncan, president of the Royal Agricultural and Horticultural Society, South Australia; Prof. W. W. Jameson, dean and professor of public health, London School of Hygiene and Tropical Medicine; Prof. R. Robinson, Waynflete professor of chemistry in the University of Oxford ; Mr. Will Spens, master of Corpus Christi College, Cambridge ; Prof. R. G. Stapledon, professor of agricultural botany, University College of Wales, and director of the Welsh Plant Breeding Station, Aberystwyth. C.B. ' Mr. A. T. A. Dobson, fisheries secretary, Ministry of Agriculture and Fisheries. C.M.G. : Mr. J. N. Oliphant, director of the Imperial Forestry Institute, Oxford. C.I.E. : Dr. W. Burns, agricultural expert to the Government of India in the Imperial Council of Agricultural Research Department ; Lieut.-Colonel G. Covell, director of the Malaria Survey of India; Mr. A. C. Hiley, chief conservator of forests, Bombay; Mr. H. B. Dunnicliff, chief chemist, Central Revenues Chemical Service, and principal of the Government College, Lahore; Lieut.-Colonel E. W. O'G. Kirwan, professor of ophthalmic surgery, Medical College, Calcutta, Bengal. C.B.E. : Mr. W. F. Brown, chief mineral adviser to the Commissioners of Crown Lands, member of the board of governors of the Imperial Institute and of the Institute's Advisory Council on Minerals; Dr. A. S. Griffith, bacteriologist, Medical Research Council; Mr. R. P. Nicholson, lately secretary of the Royal African Society; Mr. F. C. Starling, assistant secretary and director of the Petroleum Department, Mines Department.

O.B.E. : Prof. W. F. Agar, professor of zoology, University of Melbourne; Dr. H. R. Angell, senior pathologist of plant industry, Council for Scientific and Industrial Research, Commonwealth of Australia; Lieut.-Colonel K. R. Krishnaswami Ayyangar, lately director of the Pasteur Institute of Southern India, Coonoor; Mr. B. E. Frayling, chief inspector of mines, Tanganyika Territory; Mr. P. A. Godwin, director of surveys and lands, Sierra Leone; Mr. D. K. S. Grant, conservator of forests, Tanganyika Territory ; Prof. C. J. Hawkes, professor of engineering, King's College, Newcastle, member of the Departmental Committee on the Examination of Engineers in the Mercantile Marine, 1937; Mr. W. F. Higgins, secretary of the National Physical Laboratory, Department of Scientific and Industrial Research; Miss Hilda Matheson, secretary to the African Research Survey; Mr. T. Rowatt, director of the Royal Scottish Museum; Mr. J. E. A. Wolryche-Whitmore, for services to agriculture in Kenya. M.B.E. : Mr. D. O. Drummond, deputy conservator of forests, United Provinces, India; Mr. R. T. M. Hayter, assistant director of the School of Tropical Medicine and resident medical officer, Carmichael Hospital, Calcutta, Bengal ; Mr. O. H. C. Shelswell, lately personal assistant to the chief conservator of forests, Madras.

\section{Captain B. S. Cohen, O.B.E.}

Captain Bertram S. Cohen, who retired from the post of staff engineer in charge of the Post Office Research Station at Dollis Hill, London, at the end of December, has been for forty years improving instruments and developing methods used in telephony. He joined the National Telephone Co. in 1896, the year in which the Post Office bought the long-distance telephone lines throughout the United Kingdom. As early as 1900, when Sir Oliver Lodge demonstrated his hornless loudspeaker before the Institution of Electrical Engineers, Cohen was one of the first to recognize the clearness of the articulation of the device, the faithful reproduction of radio telephony greatly impressing him. In conjunction with G. M. Shepherd he did excellent work in applying some of Heaviside's work to long-distance transmission over telephone lines. With impressive thoroughness, they evaluated the solutions of the very lengthy and difficult equations, sometimes involving inverse hyperbolic functions, which were continually arising in their experimental work. Cohen contributed a paper to the Physical Society in which he discussed the alterations in the everyday solutions due to the fact that the 'constants', such as the resistance, in some of the differential equations were really variables, and the solutions consisted of terms having 
different frequencies. He received the O.B.E. for the excellent work he did in telephony during the Great War. The Institution of Electrical Engineers awarded him the Fahie Premium and an 'extra' premium for two of his papers; he is now president of the Meter and Instrument Section of the Institution. He leaves the Post Office with the good wishes of all his colleagues.

\section{South Africa's 'Men-Apes'}

THE chief findings of a report on the teeth of the fossil 'men-apes' of South Africa by Prof. W. K. Gregory and Dr. Milo Hellman of the American Museum of Natural History, New York, which are cited in a communication by them in another column of this issue of NATURE (see p. 25) tend both to confirm, and at the same time to extend, the implication of Dr. Broom's diagnosis of the human affinities of his recently discovered relics of new types of fossil prehominids. As a result of a personal inspection of the finds, these two authorities, whose judgment carries conclusive weight in view of their experience in the examination of the dentition of fossil apeforms from the Himalayan tertiary deposits, give it as their considered opinion that "the dentition of the adult forms described by Broom present many transitional or annectant conditions between the pithecoid and human stages". They go on to support and illustrate this pronouncement by reference to details of the dentition of one of these forms, namely Plesianthropus. For example, a canine of the female specimen is said to "require but little additional modification to attain the human status". What, however, is of special significance is that Prof. Gregory and his colleague find in the Indian fossil forms transitional stages leading to the almost human premolar of Plesianthropus, while another tooth of the South African type takes an intermediate position between Sivapithecus, one of the fossil anthropoids from the Siwaliks, and Peking man. A further significant suggestion, based on comparative evidence, is that the general condition of the teeth points to a stage of transition from the frugivorous habits of the ape to the omnivorous habits of man.

\section{Phylogeny and Chronology in the Descent of Man}

Ir may be noted that the conclusions at which Prof. Gregory and Dr. Hellman have arrived in regard to the dentition of the South African fossil men-apes by no means dissipate, but rather intensify, the chronological difficulties which, as has been pointed out previously, arise from these discoveries and from the inferences drawn from them by Dr. Broom. A phylogenetic succession is in process of being established in South Africa which chronologically is at variance with-that is, is later in time than - the chronological position assigned on geological and palæontological evidence to early types, definitely human in character, found elsewhere, such as, for example, Peking man. In other words, this South African series is too late in date for inclusion in the human phylum, and must belong to an analogous line of development which ultimately dies out.
Is this connexion, reference may be made to a communication which has been received from Prof. Franz Weidenreich, of the Cenozoic Research Laboratory, Peiping, who directs attention to the fact that he had already arrived at the conclusion from the Sinanthropus findings that the adoption of the upright posture and gait had preceded the decisive changes of brain and dentition; and he goes on to suggest that the parts upon which Dr. Broom relies, especially the lower end of the humerus, are not so strikingly different from those of modern chimpanzees as are the shafts and proportions of the long bones. In regard to the chronological problem in particular, he refers to two communications by himself, one appearing in Biomorphosis $(1,1 ; 1938)$, and the other presented to the Congress of Anthropological and Ethnological Seiences, Copenhagen (1938), in the course of which the discrepancy between the morphological and the chronological sequences of hominid remains is set out in detail in relation to geographical distribution. The interpretation of the evidence put forward by Prof. Weidenreich in an attempt to reconcile the two series, is that we must not look for a single place of origin in man's evolution, but that there must have been at least four centres in which the line of man has developed independently: south-eastern Asia, giving rise to the Australian type of modern man; eastern Asia, giving rise to the Mongolian ; Africa, where Rhodesian man filiates with the Negro; and Palestine or western Asia, from which the European type originated. He is careful to point out that this polycentric evolution of man does not imply a polygenetic origin.

\section{The Kut Barrage Irrigation Scheme}

THE last day of 1938 was notable in the sphere of civil engineering operations by reason of the completion of an important four-year undertaking (begun in December, 1934) which has comprised the construction in Iraq of a barrage, 1,500 ft. long, across the River Tigris, and, as an adjunct, of an irrigation canal, $2 \frac{1}{4}$ miles in length and $230 \mathrm{ft}$. wide, with a head regulator to control the flow of water down the Gharraff River. The object of the Government of Iraq in executing the work is to bring into cultivation extensive areas of land on both sides of the Shatt-elGharraff from Kut to Ur, between the Rivers Tigris and Euphrates, on the traditional site of the Garden of Eden. Previously, supplies of water have been available for the Gharraff River only during periods of flood in the Tigris; henceforward, the Kut Barrage will retain the water of the Tigris and cause it to flow at all seasons along the diversion canal into the Gharraff River. The barrage has fifty-six sluice gates, each $20 \mathrm{ft}$. wide, to control the rate of flow, while a navigation lock will enable river craft to pass the obstruction and maintain the service of boats between Bagdad and Basrah. The formation of the canal involved the excavation of $1,600,000$ cubic yards of material and the employment of 2,500 Arabs and Kurds. In addition, 250,000 cubic yards of concrete were placed in the barrage. The regulator at the head of the canal is equipped with seven sluice 